Horta, P.V.P.'; Silva, P.T.D.'; Berl, C.A'; Chalita, M.C.C.'; Maia, F.B.N.'; Kanayama, L.M.'

\section{8 - Rabdomiossarcoma de vesícula urinária em cão da Serra da Estrela adulto jovem. Relato de caso}

\author{
1- Pet Care Hospital Veterinário, São Paulo-SP
}

Um cão da Serra da Estrela, macho, com 1 ano e 10 meses, foi atendido no Hospital Veterinário Pet Care com histórico de disúria e colúria, de evolução de 15 dias. Ao exame clinico foi observado sensibilidade abdominal moderada e ao toque retal foi evidenciada estrutura septada cranial ao reto. $\mathrm{O}$ animal foi sondado sem dificuldade e realizado urinálise revelando hematúria e leucocitúria severa. $\mathrm{O}$ animal foi submetido a exame ultrassonográfico onde foi observada presença de massa luminal em parede caudo-lateral direita, em topografia de trigono vesical. Esta apresentava aspecto irregular e heterogêneo, medindo $9,2 \times 6,6 \mathrm{~cm}$. Foi então realizada punção citológica com sonda uretral guiada por ultra-som, com resultado sugestivo de neoplasia epitelial maligna. No hemograma foi evidenciado leucocitose moderada, sendo que a bioquímica sérica esteve dentro dos padròes de normalidade. $\mathrm{O}$ animal permaneceu com sonda uretral fixa por dez dias, sendo medicado com piroxican, quando retornou ao hospital com anorexia e anúria. Constatou-se que sendo a massa tumoral friável a sonda seria constantemente bloqueada por debris celulares provenientes do tumor. $\mathrm{O}$ animal foi submetido a cistocentese retirando $700 \mathrm{ml}$ de urina com sangue e grumos celulares. Optou-se pela realização de quimioterapia a base de Carboplastina com aplicações mensais. Após a primeira aplicação, não sendo evidenciada regressão da massa em três dias, o proprietário optou pela eutanásia. $\mathrm{O}$ animal foi enviado a necropsia onde se observou formação pedunculada irregular medindo $9,5 \times 7,0 \mathrm{~cm}$ de diâmetro, apresentado extensas áreas necróticas e hemorrágica. Foi observada também dilatação bilateral de ureteres $\mathrm{e}$ pelve renal. $\mathrm{O}$ exame microscópico da formação revelou tratar-se de rabdomiossarcoma embrionário vesical. As neoplasias de bexiga são raras no cão, compreendendo 0,5 a $1,0 \%$ de todas as neoplasias caninas. Rabdomiossarcoma embrionários de vesícula urinária são neoplasias malignas que começam no trígono da vesícula urinaria, possivelmente a partir de mioblastos embrionais presentes no desenvolvimento de ductos de Muller ou de Wolffian. É um tumor raro e acomete animais jovens, de idade media de 1,7 anos. Cães da raça grandes ou gigantes têm sido mais freqüentemente afetados e o São Bernardo apresenta maior predisposição. Em pacientes humanos, rabdomiosarcoma é o sarcoma de partes moles mais comum em crianças e adolescentes. O diagnóstico do tumor baseia-se na história clinica (sendo relevante a idade do animal), em estudos radiográficos e ultrassonográficos e exames citológicos. Na maioria destes tumores, a citologia é predominantemente indicativa de inflamação, e células epiteliais aparentemente anaplásicas podem ocasionalmente ser observadas em casos de moléstia inflamatória da bexiga. A melhor opção para o estabelecimento do diagnóstico definitivo é realização de biópsia que pode ser feita por cistoscopia, por cateter urinário, laparoscopia ou laparotomia. $\mathrm{O}$ tratamento baseia-se na remoção cirúrgica, em casos que não há o envolvimento de grandes extensões do trígono vesical, e a quimioterapia sistêmica a base de vincristina, ciclofosfamida ou carboplastina. $\mathrm{O}$ prognóstico é reservado pois o tumor apresenta recidivas freqüentes e metástase em $20 \%$ dos casos. 